\title{
Selection of full and half brothers families of yellow passionfruit resistant to Tetranychus mexicanus
}

\author{
Seleção de famílias irmãos completos e meios irmãos do \\ maracujazeiro amarelo resistentes ao Tetranychus mexicanus
}

\author{
Leonarda Grillo Neves ${ }^{1 *}$; Claudio Horst Bruckner²; Marcelo Coutinho Picanço²; \\ Kelly Lana Araújo ${ }^{1}$; Petterson Baptista da Luz; Marco Antonio Aparecido Barelli ${ }^{1}$; \\ Milson Evaldo Serafim ${ }^{3}$
}

\begin{abstract}
The goal of this study was to assess the behaviour of the full and half brothers families of yellow passionfruit with respect to resistance to mites (Tetranychus mexicanus), and study the alternatives of selection based on the estimated genetic gain. The 113 families of full and half brothers were assessed using randomized block designs arranged in sets, with respect to productivity of first flowering (g 21 $\mathrm{m}^{-2}$ ), which was defined from the average weight of the fruit, the number of fruits harvested in the first flowering, and the main character, which corresponded to the average number of mites per plot. The F-test showed genetic variability in the number of mites with respect to male families, and in the productivity of first flowering linked to female/male families and male families. It was observed that male variance was greater than female variance with respect to the number of mites. Consequently, there was no gene effect attributed to dominance in this character. The coefficient of male heritability regarding the number of mites was half the heritability of productivity in the first flowering, indicating that it was highly influenced by the environment. Regarding the two characters assessed, the combined selection was the one that provided the greatest selection gains.
\end{abstract}

Key words: Design I, Passiflora edulis Sims, phytophagous mite

\section{Resumo}

O objetivo deste trabalho foi avaliar o comportamento das famílias de irmãos completos e meios irmãos de maracujazeiro amarelo com relação à resistência ao ácaro rajado (Tetranychus mexicanus), e estudar as alternativas de seleção com base no ganho genético estimado. As 113 famílias de irmãos completos e meios irmãos foram avaliados, usando-se o delineamento em blocos ao acaso em arranjo em sets, com

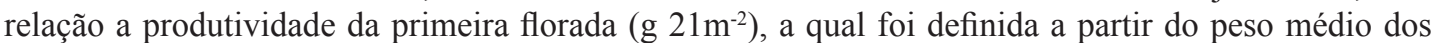
frutos, e pelo número de frutos colhidos na primeira florada (PPFP) e o caracter principal, neste estudo, o número médio de ácaros por parcela (NA). $\mathrm{O}$ teste $\mathrm{F}$, acusou variabilidade genética para número de ácaros com relação às famílias de machos e para produtividade da primeira florada em vinculada às famílias de fêmeas/machos e famílias de machos. Pode-se verificar que a variância de macho foi maior que a variância de fêmea, para o caracter, número de ácaros. Consequentemente, para esse caracter não

1 Profs., Universidade do Estado de Mato Grosso, UNEMAT, Cáceres, MT, Brasil. E-mail: leonardaneves@unemat.br; kellylana araujo@yahoo.com.br; mbarelli@unemat.br; petterbaptista@yahoo.com.br

2 Profs., Universidade Federal de Viçosa, UFV, Viçosa, MG, MG, Brasil. E-mail: bruckner@ufv.br; picanco@ufv.br

3 Prof., Instituto Federal de Educação, Ciência e Tecnologia de Mato Grosso, IFMT, Cáceres, MT, Brasil. E-mail: milsonserafim@ gmail.com

* Author for correspondence 
houve efeito gênico atribuído a dominância. O coeficiente de herdabilidade, em nível de machos, para número de ácaros foi a metade da herdabilidade para produtividade na primeira florada, indicando ser altamente influenciada pelo ambiente. Nos dois caracteres avaliados, a seleção combinada foi a que proporcionou os maiores ganhos de seleção.

Palavras-chave: Delineamento I, Passiflora edulis Sims, ácaro fitófago

\section{Introduction}

The yellow or sour passionfruit belongs to the species Passiflora edulis Sims (BERNACCI et al., 2008). It is an alogamic plant conditioned by self-incompatibility (SUASSUNA et al., 2003). The genetic improvement of the passionfruit had increase in productivity and quality of fruits as the initial goal targeting the market of fresh or industrial fruit (KRAUSE et al., 2012; ROSADO et al., 2012). Subsequently, the goal of disease resistance was added (KUDO et al., 2012). Resistance to insects has been incorporated into the improvement of several species (BALDIN et al., 2005). The mechanisms of resistance are varied and complex, and they can be grouped into: no insect's preference for the plant; antibiosis; and tolerance (PAINTER, 1951).

Although not considered a key pest, the Mexican mite (Tetranychus spp.) (Acari: Tetranychidae) emerges as a pest in the passionfruit as a result of the elimination of natural enemies and other antagonist organism of mites in the crops.

As a result of the development of the resistance of mites to pesticides - found in diverse crops (VAN LEEUWEN et al., 2010) - it is necessary to adopt management techniques that take into account the preservation of natural enemies and the reduction of environmental damage caused by agrochemicals. Regarding pests management, it is important to research the genetic resistance of plants to pests. According to Noronha (2006), passionfruit crops are hostesses of phytophagous mites belonging mainly to the families Tarsonemidae, Tenuipalpidae, and Tetranychidae. Tetranychus mexicanus is among the tetraniquid species. Dominguez-Gil and Mc Pheron (1992) reported T. mexicanus as an important pest of passionfruit in periods of low rainfall.
The Mexican mite Tetranychus spp. is polyphagous and has several plant species as hosts, such as passionfruit, peach-palm, and annonaceae (DOMINGUEZ-GIL; MCPHERON, 1992; SOUSA et al., 2010; STEIN; DAÓLIO, 2012). The control of mite of the genus Tetranychus spp. has been carried out using synthetic chemical pesticides (VERONEZ et al., 2012), plant extracts (ERDOGAN et al., 2012), and biological control (GRECO et al., 2011). The possibility of control by genetic resistance has been studied in vine (VALADÃO et al., 2012) and cotton (MIYAZAKI et al., 2012).

Mites have enormous capacity for population increase, reaching from 20 to 25 generations per year. In this way, mite control should be efficient, keeping the population below the level of economic damage. Currently, the chemical control is the most widely used; however, it is the most problematic, because, according to Maruyama et al. (2002), mites have great ability to develop resistance against various groups of acaricides. Within that context, the gain with selection of passionfruit families that combine productivity with lower economic damage regarding mites attack can be of great value.

The goal of this study was to assess the behaviour of the full and half brothers families of yellow passionfruit with respect to resistance to mites (Tetranychus mexicanus), and study the alternatives of selection based on the estimated genetic gain.

\section{Material and Method}

In the Programme for the Improvement of the Passionfruit of the Norte Fluminense State University (UENF), plants were sampled in the area of Bela Joana Company, Campos dos Goytacazes, 
State of Rio de Janeiro, in 2006. These plants were from the populations: materials from São Francisco do Itabapoana, Maguary and Yellow Máster. Interbreeding followed the procedure of Comstock and Robinson's Design I described by Hallauere Miranda Filho (1988).

In order to carry out the present study, the 113 half and full brothers families were installed in Viçosa, MG, State of Minas Gerais $\left(20^{\circ} 45^{\prime} \mathrm{S}\right.$ and $42^{\circ} 53^{\prime} \mathrm{W}$, at $648 \mathrm{~m}$ altitude), in collaboration between the State University of Norte Fluminense (UENF) and the Federal University of Viçosa (UFV). The number of male progenitors involved in interbreeding was varied. This way, a total of 113 families were obtained using randomized block designs arranged in sets (treatments group) composing three of them. Set one included one to 40 treatments, set two 41 to 80 , and set three 81 to 113 . Random block designs were used in each set with three replications.

The natural incidence of mites was quantified by the average number of adults. The count was made in the field in the tertiary branch, first, second, and third leaves. The determination of the number of mites (NM) was made directly using a magnifying glass, $50 \mathrm{~mm}$ in diameter and 3.5 times increase (Magnifier $8250 \mathrm{G}$ ) and the visual field was stipulated at $2.5 \mathrm{~cm}^{2}$.

The count was held in the tri-lobed passionfruit leaves on the abaxial surface, in the two points of intersection central to the vein. The number of mites was obtained from the sum of the two quadrants of each leaf of the plants, and the average of the three plants per plot.

The 113 full and half brothers families were assessed per plot regarding the productivity of the first blooming (g $21 \mathrm{~m}-2$ ), which was defined from the average weight of the fruits, the number of fruits harvested in the first flowering (PFP), and the main character-in this study corresponding to the average NM per plot.

Analyses of variance were performed for each character assessed, using the GENES, Genetics and
Statistics programme, version 2009, according to Cruz (2006). The model was established with all the random effects, as follows:

$$
\mathrm{Y}_{\mathrm{ijk}}=\mu+\mathrm{M}_{\mathrm{i}}+\mathrm{F} / \mathrm{M}_{\mathrm{ij}}+\mathrm{B}_{\mathrm{k}}+\varepsilon_{\mathrm{ijk}}
$$

$\mathrm{Y}_{\mathrm{ijk}}=$ observation of the interbreeding between male $\mathrm{i}$ and female $\mathrm{j}$;

$\mu=$ overall average;

$\mathrm{M}_{\mathrm{i}}=$ effect of the $\mathrm{i}$ order male progenitor (male);

$\mathrm{F} / \mathrm{M}_{\mathrm{ij}}=$ effect of the female $\mathrm{j}$ progenitor (female) hierarchised within male $\mathrm{i}$;

$\mathrm{B}_{\mathrm{k}}=$ effect of repetition of $\mathrm{k}$ order;

$\varepsilon_{\mathrm{ijk}}=$ experimental error.

The analysis model $\mathrm{Y}_{\mathrm{ijk}}=\mu+\mathrm{M}_{\mathrm{i}}+\mathrm{F} / \mathrm{M}_{\mathrm{ij}}+\mathrm{B}_{\mathrm{k}}$ $+\varepsilon_{\mathrm{ijk}}$ was established from the grouping correction (set). Considering: $\mathrm{Z}_{\mathrm{ijkl}}=\mu+\mathrm{S}_{1}+\mathrm{B} / \mathrm{S}_{\mathrm{il}}+\mathrm{M} / \mathrm{S}_{\mathrm{ijl}}+$ $\mathrm{F} /(\mathrm{MS})_{\mathrm{i}(\mathrm{jl})}+\varepsilon_{\mathrm{ijk} \mathrm{l}}$, there is $\mathrm{Y}_{\mathrm{ijk}}=\mathrm{Z}_{\mathrm{ijkk}}-\mathrm{S}_{1}$ with $\mathrm{S}_{1}=\overline{\mathrm{Z}}$ $-\bar{Z}$

In order to estimate the components of genotypic variance, additive genetic variance, and genetic variance due to dominance deviations among individuals of a population, the variance components were expressed in association with the effects of genetic nature of the statistical model $\hat{\sigma}_{m}^{2}$ e $\hat{\sigma}_{f / M}^{2}$ based on the additive genetic variance $\left(\hat{\sigma}_{a}^{2}\right)$ and the genetic variance attributed to dominance deviations $\left(\hat{\sigma}_{d}^{2}\right)$. This way, it was possible to obtain the estimates of these parameters from the equations that involve the average squares of the analysis of variance.

Considering the statistical model used, the following models of heritability were calculated: heritability at male level (selection based on the average of male progenitors); heritability at female level within male (selection based on female progenitors for each male genitor); and heritability at female level (selection based on the average female genitors).

The prediction of genetic gains from the selection was performed considering the alternatives of 
selection derived from the Design I (CRUZ; CARNEIRO, 2003; FURTADO, 1996):

- Selection based on the behaviour of the male progenitor (male): the selection gain was estimated from five families, relating to nine male progenitors that exhibited higher averages.

- Selection based on the behaviour of females/ males: the gain was estimated through the selection of families, with the contribution of all male progenitors assessed to integrate the new recombinant population, selecting the best two families of each male progenitor, making a total of 46 families selected as superior;

- Selection based on the behaviour of female progenitors (females): the gain was estimated selecting the best 45 families, regardless of the group of male progenitors to which they belonged;

- Selection between and within male progenitors: the gain was estimated assessing the selection of the fifteen best male progenitors and, within each progenitor, the three best families, making a total of
45 families genetically superior; and

- Combined Selection: the gain was estimated with the selection of the best 45 families, regardless of the male progenitor to which they belonged, based on their scores obtained from the combined index.

\section{Results and Discussion}

The results of the analysis of variance regarding the characters NM and PFP are illustrated in Table 1. The coefficients of variation found exhibited values of different magnitudes, which was already expected, because this coefficient that measures the experimental precision is also a peculiarity of the character. With respect to the character PFP, it was observed a variation coefficient of $46.43 \%$, and for NM the coefficient of variation was $76.31 \%$. Usually, regarding studies on resistance both for pests and diseases it is common to find high coefficients due to the fact that they are related to the interaction of more than one living organism (host-parasite).

Table 1. Analysis of variance of the characters Number of Mites (NM) and Productivity of the First Flowering (PFP) in 113 full and half brothers families of yellow passionfruit using the hierarchical model proposed by Comstock and Robinson (1948).

\begin{tabular}{cccc}
\hline \multirow{2}{*}{ Source of Variation } & \multirow{2}{*}{ G. L. } & \multicolumn{2}{c}{ Q. M. } \\
\cline { 3 - 4 } & 2 & 92.80 & PFP \\
\hline Blocs & 22 & $46.85^{*}$ & 4.04 \\
Males & 90 & $29.14^{\text {ns }}$ & $27.87^{* *}$ \\
Females/Males & 224 & 27.50 & $11.67^{* *}$ \\
Residue & 338 & & 3.97 \\
\hline Total & & 6.87 & 4.29 \\
Average & 76.31 & 46.43 \\
\hline
\end{tabular}

$(* *)(*)=$ Significant from $1 \%$ to $5 \%$ probability, respectively; $\left({ }^{\text {ns }}\right)=$ no significant difference found using the F-test.

In Comstock Robinson's Design I (1948) used in the present study, the degrees of freedom concerning progenies were broken down into families of male progenitors (males) and families of female progenitors within males.
The F-test revealed genetic variability with respect to the NM in male families. There was variance through the F-test for PFP regarding female/male families and male families (Table 1). The gains to be obtained should be differentiated 
depending on where the genetic variability of each character could be explored, i.e., males and/or females within males, depending on the variability, which will determine the possibility of obtaining selection gains..

The components of variance associated with the effects of males $\left(\hat{\sigma}_{m}^{2}\right)$, the effects of females within males $\left(\hat{\sigma}_{f / m}^{2}\right)$, and the total genetic effects of progenies $\left(\hat{\sigma}_{g}^{2}=\hat{\sigma}_{m}^{2}+\hat{\sigma}_{f / m}^{2}\right)$, referring to all characters are illustrated in Table 2. These variance components were expressed in average progeny level, but they also reflect the degree of genetic variance among individuals in the population.

Table 2. Estimate of variance components associated with the statistical model and heritability coefficients, considering the units of selection with respect to the characters Number of Mites (NM) and Productivity of the First Flowering (PFP) in yellow passionfruit.

\begin{tabular}{ccc}
\hline Components & $\mathrm{NM}$ & $\mathrm{PFP}$ \\
\hline$\hat{\sigma}_{\mathrm{m}}^{2}$ & $1.2017^{*}$ & $1.0991^{* *}$ \\
$\hat{\sigma}_{\mathrm{f} / \mathrm{m}}^{2}$ & $0.5445^{\mathrm{ns}}$ & $2.5653^{* *}$ \\
$\hat{\sigma}_{\mathrm{g}}^{2}$ & 1.7462 & 3.6644 \\
$\hat{\sigma}_{\mathrm{a}}^{2}$ & 4.807 & 4.3963 \\
$\hat{\sigma}_{\mathrm{d}}^{2}$ & -2.629 & 5.8649 \\
$\mathrm{CVa}$ & 0.319 & 0.4268 \\
$\mathrm{~h}_{\mathrm{M}(\mathrm{A})}^{2}$ & 41.29 & 85.74 \\
$\mathrm{~h}_{\mathrm{M}(\mathrm{R})}^{2}$ & 45.5 & 69.95 \\
$\mathrm{~h}_{\mathrm{F}(\mathrm{A})}^{2}$ & 5.61 & 73.24 \\
$\mathrm{~h}_{\mathrm{F}(\mathrm{R})}^{2}$ & 12.37 & 43.62 \\
$\mathrm{~h}_{\mathrm{F} / \mathrm{M}(\mathrm{A})}^{2}$ & 15.67 & 65.94 \\
$\mathrm{~h}_{\mathrm{F} / \mathrm{M}(\mathrm{R})}^{2}$ & 21.72 & 28.25 \\
\hline
\end{tabular}

$\left({ }^{* *}\right)(*)=$ Significant from $1 \%$ to $5 \%$ probability, respectively; $\left({ }^{\mathrm{ns}}\right)=$ no significant difference found using the F-test.

Table 2 shows that $\hat{\sigma}_{m}^{2}$ was greater than $\hat{\sigma}_{\mathrm{f} / \mathrm{m}}^{2}$ for the character NM. Consequently, there was no gene effect attributed to dominance regarding that character $\left(\hat{\sigma}_{d}^{2}\right)$, i.e., they were calculated as being negative.

The heritability coefficient showed the highest value at males level, both for NM $(45.5 \%)$ and PFP $(69.85 \%)$ (Table 2). The heritability coefficients in the narrow sense which are used in the calculation of expected responses to the selection indicate expected progress for the improvement of these two characters. In addition, this coefficient, at males level, was generally half the heritability of PFP, indicating lower progress with the selection, since an important function of heritability, in the narrow sense, is its predictive role, expressing confidence 
of the phenotypic value as genetic value estimator as reported by Falconer and Mackay (1996). The lowest heritability concerning NM, which expresses the lowest possible gain in the selection, can be explained by the variability observed, which is more favourable to selection of plants that are more productive than resistant to mites. Resistance to mites, in turn, probably depends not only on the variability of the host, but also the variability of mites.

$\hat{\sigma}_{m}^{2}, \hat{\sigma}_{f / m}^{2}, \hat{\sigma}_{g}^{2}$ Estimate of variance components associated with the effects of genetic nature of the statistical model: effects of males, females within males, and progeny, respectively.

$\hat{\sigma}_{a}^{2}, \hat{\sigma}_{d}^{2}$ Estimate of genetic variance components between the individuals of the population:

additive genetic variance and genetic variance attributed to the dominance deviations, respectively.

$\mathrm{CVa}=\frac{\sqrt{\hat{\sigma}_{\mathrm{a}}^{2}}}{\mathrm{~m}}$ Estimate of the additive genetic variance component $\hat{\sigma}_{\mathrm{g}}^{2}=\hat{\sigma}_{\mathrm{m}}^{2}+\hat{\sigma}_{\mathrm{f} / \mathrm{m}}^{2}$.

$h_{M(A)}^{2}, h_{M(R)}^{2}$ Heritability in average male level in broad and narrow senses.

$\mathrm{h}_{\mathrm{F}(\mathrm{A})}^{2}, \mathrm{~h}_{\mathrm{F}(\mathrm{R})}^{2}$ Heritability in average female level in broad and narrow senses.

$\mathrm{h}_{\mathrm{F} / \mathrm{M}(\mathrm{A})}^{2}, \mathrm{~h}_{\mathrm{F} / \mathrm{M}(\mathrm{R})}^{2}$ Heritability in average female within male level in broad and narrow senses.

The comparison of the strategies of selection assessed using Comstock Robinson's Design I (1948) showed that the combined selection (CS) was the one that provided the greatest gains of the selection. As can be seen in Table 3, there was estimate of $24.13 \%$ increase in the character PFP and $11.54 \%$ decrease in NM in the constitution of a new population from the females selected by CS.

Table 3. Estimate of selection gain (SG\%) for the characters Number of Mites (NM) and Productivity of the First Flowering (PFP) in yellow passionfruit from the selections: SBM; SF/M; SBF; SF/MALESs; and CS.

\begin{tabular}{ccc}
\hline \multirow{2}{*}{ Selection alternative } & \multicolumn{3}{c}{$\mathrm{SG} \%$} \\
\cline { 2 - 3 } & $\mathrm{NM}$ & $\mathrm{PFP}$ \\
\hline SBM & -11.00 & 22.06 \\
SF/M & -4.38 & 10.94 \\
SBF & -8.93 & 22.71 \\
SF/MALESs & -10.22 & 19.56 \\
CS & -11.54 & 24.13 \\
\hline
\end{tabular}

$\mathrm{SBM}=$ selection between males; $\mathrm{SF} / \mathrm{M}=$ selection of females/males (all males); $\mathrm{SBF}=$ selection between females (regardless of males); SF/MALESs = selection of females/males selected; and CS = combined selection.

The CS uses a value that is attributed to the females of the experiment replacing each character according to the assertions of Furtado (1996), and Cruz and Carneiro (2003). The value of this CS index for each of the two characters studied was then given to a certain female based on its performance and the performance of the male family in which it was inserted. The combined index was that in which the value of the family is given by the linear combination of the family's average and the average of its relatives for each character.
In this case, the index value appropriately attributed was the heritability of males and females within males, both in the narrow sense, for deviation of males and females within males. Thus, the results revealed that the best of the selection alternatives assessed was the CS.

Full and half brothers families of passionfruit numbered 4, 12, 15, 16, 17, 35, 37, 40, 41, 43, 44, $45,46,48,49,52,76,78,79,80,81,84,85,94$, $97,101,105$, and 106 were the 28 families selected 
in common for the two characters simultaneously. Therefore, they are indicated to be recombined and give rise to the next selection cycle, along with 16 more families to be directed from the analysis.

\section{Conclusion}

The full and half brothers families of yellow passionfruit studied exhibited variability to be exploited in the selection, aiming at productivity and resistance to mites. Among the alternatives studied for the two characters assessed, the CS provided the greatest selection gains.

\section{References}

BALDIN, E. L. L.; VENDRAMIM, J. D.; LOURENÇÃO, A. L. Resistência de genótipos de tomateiro à moscabranca Bemisia tabaci (Gennadius) biótipo B (Hemiptera: Aleyrodidae). Neotropical Entomology, Londrina, v. 34, n. 3, p. 435-441, 2005.

BERNACCI, L. C.; SOARES-SCOTT, M. D.; JUNQUEIRA, N. T. V.; PASSOS, I. R. S.; MELETTI, L. M. M. Passiflora edulis Sims: the correct taxonomic way to cite the yellow passion fruit (and of others colors). Revista Brasileira de Fruticultura, Jaboticabal, v. 30, n. 2, p. 566-576, 2008.

COMSTOCK, R. E.; ROBINSON, H. F. The components of genetic variance in populations of biparental progenies and their use in estimating the average degree of dominance. Biometrics, Washington, v. 4, p. 254-266, 1948.

CRUZ, C. D. Programa genes: biometria. Versão Windows; aplicativo computacional em genética e estatística. Viçosa: UFV, 2006. 382 p.

CRUZ, C. D.; CARNEIRO, P. C. S. Modelos biométricos aplicados ao melhoramento genético. Viçosa: UFV, 2003. $585 \mathrm{p}$.

DOMINGUEZ-GIL, O. E.; MCPHERON, B. A. Arthropods associated with passion fruit in western Venezuela. The Florida Entomologist, Gainesville, v. 75, n. 4, p. 607-612, 1992.

ERDOGAN, P.; YILDIRIM, A.; SEVER, B. Investigations on the effects of five different plant extracts on the two-spotted mite Tetranychus urticae koch (Arachnida: Tetranychidae Tetranychidae). Psyche, Cambridge, v. 2012, p. 1-5, 2012.
FALCONER, D. S.; MACKAY, T. F. C. Introduction to quantitative genetics. London: Logman, 1996. 464 p.

FURTADO, M. R. Alternativas de seleção no delineamento I de Comstock e Robinson, em milho. 1996. Tese (Doutorado em Genética e Melhoramento) Universidade Federal de Viçosa, Viçosa, MG.

GRECO, N. M.; LILJESTHRÖM, G. G.; GUGOLE OTTAVIANO, M. F.; CLUIGT, N.; CINGOLANI, M. F.; ZEMBO, J. C.; SÁNCHEZ, N. E. Pest management plan for the two-spotted spider mite, Tetranychus urticae, based on the natural occurrence of the predatory mite Neoseiulus californicus in strawberries. International Journal of Pest Management, London, v. 57, n. 4, p. 299308, 2011.

HALLAUER, A. R.; MIRANDA FILHO, J. B. Quantitative genetics in maize breeding. 2th ed. Ames: Iowa State University Press, 1988. 468 p.

KRAUSE, W.; SOUZA, R. S.; NEVES, L. G.; CARVALHO, M. L. S.; VIANA, A. P.; FALEIRO, F. G. Ganho de seleção no melhoramento genético intrapopulacional do maracujazeiro-amarelo. Pesquisa Agropecuária Brasileira, Brasília, v. 47, n. 1, p. 51-57, 2012.

KUDO, A. S.; PEIXOTO, J. R.; JUNQUEIRA, N. T. V.; BLUM, L. E. B. Suscetibilidade de genótipos de maracujazeiro-azedo à septoriose em casa de vegetação. Revista Brasileira de Fruticultura, Jaboticabal, v. 34, n. 1, p. 200-205, 2012.

MARUYAMA, W. I.; TOSCANO, L. C.; BOIÇA JÚNIOR, A. L.; BARBOSA, J. C. Resistência de genótipos de tomateiro ao ácaro rajado. Horticultura Brasileira, Brasília, v. 20, n. 3, p. 480-484, 2002.

MIYAZAKI, J.; STILLER, W. N.; WILSON, L. J. Novel cotton germplasm with host plant resistance to two spotted spider mite. Field Crops Research, Narrabri, v. 134, p. 114-121, 2012.

NORONHA, A. C. S. Biological aspects of Tetranychus marianae McGregor (Acari, Tetranychidae) reared on yellow passion fruit (Passiflora edulis Sims f. flavicarpa Deg.) leaves. Revista Brasileira de Zoologia, Curitiba, v. 23, n. 2, p. 404-407, 2006.

PAINTER, R. H. Insects resistance in cropplants. New York: Mcmillan, 1951. $520 \mathrm{p}$.

ROSADO, L. D. S.; SANTOS, C. E. M. D.; BRUCKNER, C. H.; NUNES, E. S.; CRUZ, C. D. Simultaneous selection in progenies of yellow passion fruit using selection indices. Revista Ceres, Viçosa, MG, v. 59, n. 1, p. 95-101, 2012. 
SOUSA, J. M.; GONDIM JUNIOR, M. G. C.; LOFEGO, A. C. Biologia de Tetranychus mexicanus (McGregor) (Acari: Tetranychidae) em três espécies de Annonaceae. Neotropical Entomology, Londrina, v. 39, n. 3, p. 319$323,2010$.

STEIN, C. P.; DAÓLIO, N. Biologia de Tetranychus mexicanus (McGregor) (Acari: Tetranychidae) em folhas de Pupunha (Bactris gasipaes Kunth). Bioikos, Campinas, v. 26, n. 1, p. 23-28, 2012.

SUASSUNA, T. M. F.; BRUCKNER, C. H.; CARVALHO, C. R.; BORÉM, A. Self-incompatibility in passionfruit: evidence of gametophytic-sporophytic control. Theoretical and Applied Genetics, Berlin, v. 106, n. 2, p. 298-302, 2003.
VALADÃO, G. S.; VIEIRA, M. R.; PIGARI, S. A. A.; TABET, V. G.; SILVA, A. C. Resistência de cultivares de videira ao ácaro-rajado Tetranychus urticae na região de Jales, estado de São Paulo. Revista Brasileira de Fruticultura, Jaboticabal, v. 34, n. 4, p. 1051-1058, 2012.

VAN LEEUWEN, T.; VONTAS, J.; TSAGKARAKOU, A.; DERMAUW, W.; TIRRY, L. Acaricide resistance mechanisms in the two-spotted spider mite Tetranychus urticae and other important Acari: a review. Insect Biochemistry and Molecular Biology, Oxford, v. 40, n. 8, p. 563-572, 2010.

VERONEZ, B.; SATO, M. E.; NICASTRO, R. L. Toxicidade de compostos sintéticos e naturais sobre Tetranychus urticae e o predador Phytoseiulus macropilis. Pesquisa Agropecuária Brasileira, Brasília, v. 47, n. 4, p. 511-518, 2012. 